\title{
Women and Education: Women Movements Through Poems in Two Newspapers Perempoean Bergerak (1919) and Bintang Karo (1931)
}

\author{
Sartika Sari \\ LPDP (Indonesia Endowment Fund for Education) Awardee \\ Faculty of Cultural Sciences, Universitas Padjadjaran, Indonesia \\ Email:ssartika6@gmail.com
}

\begin{abstract}
This study discusses how issues about women and education featured in poem Tjoemboean, published in newspapers Perempoean Bergerak (1919) and Adjakan (Doenia Istri), published in newspapers Bintang Karo (1931). The newspapers were printed and distributed in Northern Sumatra and Aceh. In publication and preparation process, the newspapers of Perempuan Bergerak (1919) and Bintang Karo (1931) were dominated by women. This information was founded in official statement of editorial staff structure printed on the opening page. Generally, column contents which were published in the newspapers consisted of poems, short essays, and advertisements. Mostly, the newspapers discussed various issues related to women's lives. This study finds that two poems Tjoemboean and Adjakan in the newspapers were used as a tool of critical articulation of women's issues about their lives. In particular, the poems reveal, first, women's education has a strong relationship with the issue of property, parents, and love. Second, education is a means to improve the quality of women's self to be free from gender subordination. Third, the women's movement in the years of 1919-1931 in the region of Northern Sumatra focuses on education issues are conveyed through newspapers.
\end{abstract}

Keywords: Movement; NorthernSumatra; Poem; Women;

\section{Introduction}

Perempoean Bergerak newspaper first published on May 15, 1919. The director was T.A. Sabariah, accompanied by Boetet Satidjah as editor, and Parada Harahap as Chief Editor. The slogan that the newspaper carried was "Published For Advocated Women Movement". In "Salam Redactie" column, the emergence of this newspaper explained in more detail, namely to support the movement of women to have equal opportunities in the national struggle. In addition, the newspaper intended to publish the works that were beneficial to women. For example about the household guard, customs, manners, life wife, child care, and daily life. Occurrenceof Perempoean Bergerak, according to Samry (2014), was a sign of the initial women movement in Northern Sumatera.

Perempoean Bergerak published at the same time as the founding of Balai Pustaka. Apart from whether the newspaper was founded to fight Balai Pustaka or not, the discourse presented by Perempoean Bergerak contrary to the discourse presented by Balai Pustaka. Sumardjo (1981) recognized that in this period, precisely since the 1920 s, women in Indonesian literature have become the main conversation. The existence of women were often juxtaposed with the cultural clash between the old and new cultures. Women werepeople who 'controlled by parents'. For example as depicted in the novels Siti Nurbaya by Marah Rusli, Tenggelamnya Kapal Van Der Wijck by Hamka, and Layar Terkembang by Sutan Takdir Alisyahbana that published by Balai Pustaka. All of the novels were written by men. This fact is reinforced by Samboedja analysis (2008) that since 1917, Balai Pustaka indeed had published literary works were mostly written by men, while women writers were less. Then, in the 1930s, as Sumardjo said (1981), emerged women authors such as Hamida, Soewarsih Djojopuspito, and Selasih Selaguri Sariamin from a group of Pujangga Baru.

Furthermore, Bintang Karo newspaper I researched was published in 1931. The newspaper was managed by NR. Poerba and Marah Oedin Harahap. The editors were S. Manir and Siti Hasnah Lubis. Editorial offices located in Kabanjahe. Bintang Karo contained many writings relating to various issues in the region of Kabanjahe. But, there were also writings that discussed Indonesian generally. If it is contextualised from Indonesian literature point of view, the newspaper appeared in the early days of emergence of Pujangga Baru that ideologically, according to Rosidi (2013), brings freedom of works. 
Poems was selected as a medium to convey woman critical thought at the time. According to Kaplan via Gamble (2010), it was not only about courage to write and to fight for one's own self, but also part of political resistance process. Thus, the movement carried out by women reached the public domain. Resistance became one of the components of action of writing for women. For example, the resistance that Touring Lanyer have done in UK through a collection of poem and prose Salve Rex deus Judaeorum. Exclusively the collection of poems and prose were intended to unite the power of women. The poems became an atention because of discussing feminist theology, reconstructing, and providing a new view of women in the Bible (Hodgson-Wright via Gamble, 2010).

Poems called Tjoemboean and Adjakan (Doenia Istri), each has content of the same resistance, but moves at a different level. Both of poems showed the movement through a critical analysis of the issue of women's education. That view is in line with the spirit of the women's movement in the nineteenth century. As Wieringa discussed (1999) that the first activity of emergence of women's movement is to open schools for women, including a small school house which was established by Kartini, either at her house or at her husband's. Furthermore, women school that was founded by Dewi Sartika in Bandung in 1904 and the eight other girls schools that were founded aboout in 1912. In Western Sumatera, Hanani (2011) stated that in 1911 also established a school for Minang women by Rohana Kudus. Movement to fight for women's education is also done through formal organization. According to Blumberger in Wieringa's analysis (1999), the first women's organization in Indonesia named Putri Mardika founded in Jakarta in 1912. The organization aims to fight for the education of women, encourages women to appear in public, throws the feeling of "fear", and "elevates" women to the same status as men.

As the feminist movement, according to Mcdonald (2001), the movement that carried out by women is a movement that is based on the view that women are in the position of the oppressed, subordinated in the system, and imprisoned ideologically. The thought is at once reflected structural changes in the lives of women. Thus, the women's movement is a heterogeneous movement, which has a variety of theoretical and political views.

This movement, in Wollstonecraft's view as analyzed by Arivia (2003) aims to put women at themselves, as a person, and as a rational agent who has the ability and will of self. One of the ways to achieve the position is to improve the quality of women's education. Thus, expressing the inequalities and problems faced by women in education, through poem in newspaper, as women did in Northern Sumatra, indicates that the issue was crucial and becomes something championed. Within this framework, I will show how poems Tjoemboean and Adjakan (Doenia Istri) represent the women's movement in Northern Sumatra through critical thinking to the problems of education.

\section{Discussions}

\subsection{Women's Movement of Tjoemboean}

Movement shown in poems of Tjoemboean and Adjakan (Doenia Istri) can be identified as a movement that offers liberation of women from gender subordination through education. Some other issues for example about jewelry and love are the matters that considered influential in obtaining to educational rights for women.

The excitement is in line with liberal feminist agenda, in Arivia's analysis (2003), which is fighting for the rights of women in politics, education, and employment. As a whole agenda pursued through legal channels by way of reforming the existing system to achieve equality for women who championed mainly through legality approach.

What women have done through both poems, according to Wieringa (1999) is part of the movement. This is because, according to Wieringa (1999), the women's movement did not speak in single language. But in essence, the women's movement can be seen as a comprehensive spectrum of individual or collective act consciously and unconsciously, activities, groups or organizations that focus on various aspects of gender subordination is seen intertwined with other oppressions.

Through poems, of Tjoemboean and Adjakan (Doenia Istri), the women's movement is shown in two positions. The first is women as young people (students). Second, women as the mothers. The 'vehicle' offered to fight for the rights of women themselves in these two positions is education.

Teman sekalian muda yang pu'ta

Tuntutlah segala ilmu yang nyata
Supaya laki-laki menghargai kita

Jangan dibuatnya sebarang kata 
Sanak saudara usul yang syahda

Tuntutlah ilmu-ilmu yang ada

Tuan penuhkan di dalam dada

Guna disebarkan di Hindia-Belanda

Wahai tuan jangan manja

Satukan kepelajaran saja

Dalam belajar baiklah kerja

Biar pagi ataupun senja

Ibu bapak baik di hormat

Kepada guru tetap berkhimat

Teruskan belajar sampai tamat

Supaya badan nanti selamat

Zaman ini zaman kemajuan

Tuntutlah ilmu wahai tuan

Supaya maju bangsa perempuan

Usah laki-laki selamanya duluan

Abad ke XX orang katakan

Bangsa inlander cinta dimajukan

Laki-laki perempuan jangan

dibedakan

Sebab ilmu tak tertentukan

All young and noble friends

Seek real entire knowledges
So that men respect to us

Not to be made as any words

Glorious sisters

Seek existed knowledges

You fill them up in the chest

To spread in Dutch East Indies

O you! Do not be spoiled

Just unite the lessons

In learning, be good at doing

Whether in the morning or at the dusk

The Mothers and Fathers, good to be honored To the teachers keep polite

Continou studying until finish

So that the body is later safe

This era is onward

Seek knowledges $\mathrm{O}$ you

So that become onward the women

Not the men always be the first

XX century people said

Inlander nation loved to be promoted

Men and women do not be distinguished

Because knowledge is not to decide

Some verses of the poem of Tjoemboean show an allurement addressed to woman students. In this context, I am arguing that the woman in question is unmarried woman. It is based on the clues contained in the poem through a line "The Mothers and Fathers, good to be honored / To the teachers keep polite" which indicates that the target object still has a big responsibility to comply with the norms that exist between herself and her mother, father, and teacher. This responsibility is coupled with other advice in order to 'women in question' as soon complete his education. Both of these characteristics are very close to the situation of women who have not been under the influence of a husband or a household power.

Awareness efforts of women to be more diligent study aims to make men respect women and for the advancement of women themselves. This thought is expressed in lines "Seek real entire knowledges/So that men respect to us". Other ideas that underlie the emergence of such suggestions are awareness that it is time for women to be bold to balance or precede the progress of men. Through the verse "This era is onward/Seek knowledges $\mathrm{O}$ you/So that become onward the women/Not the men always be the first" the poem of Tjoemboean invites women to realize the vision of that progress. Women provoked to immediately make a movement, one of the ways with what was Millet said (1970) which is against the control that have been done by men to women themselves.

Another invitations conveyed by poem of Tjoemboean is to make women as disseminator agents of science on society and nation. The desire to put women as the agents, in my opinion, politically derived from the awareness of women to be engage in national movement. On the other hand, as Nanditha Gandhi said in Kuria's study via Gamble (2010) the actions were an attempt to move out of the domestic area that limited and full with responsibility imposed by society.

In addition to the issue of women with men that vocalized as public affairs, poem of Tjoemboean also sued the constructions built by government agencies or in the case of acquisition of education. On this, I think, what Stuers disclosed via Wiyatmi, (2013) are quite representative that at the Dutch colonial period, there's only a few women, especially from nobleman society groups, who has had the opportunity to take a formal education, while 
the other groups only received non-formal education and literacy. Through verse, "XX century people said/Inlander nation loved to be promoted/Men and women do not be distinguished/ Because knowledge is not to decide", that claim was delivered emphatically. Women demand the same equality and freedom in obtaining space as well as the opportunity to study.

\subsection{Women's Movement in Adjakan}

Poem of Adjakan (Doenia Istri) contains appeal and invitation to move, improve the lives of the mothers through education. This poem was published by Bintang Karo newspaper that circulated in region of Kabanjahe.

Ilmu itu harta yang kekal

Tentulah ia jangan tertinggal

Walau di darat atau di kapal

Itu boleh menjadi bekal

Sebab kaum ibu zaman sekarang

Menuntutlah ilmu amatlah jarang

Hingga pengetahuan amatlah kurang

Ambilah cermin ke tanah Seberang

Tapi kalau kita rajin belajar

Segala ilmu dapat dikejar

Sehingga boleh jadi pengajar

Kalau kita sudahlah pintar

Kalau kita sudahlah pandai

Segala maksud mudah tercapai

Dapat naik sebagai tupai

Baunya pun harum bak bunga teratai

Dari sebab itu wahai kawanku

Mari kita satu persatu

Dengan segera rencana ilmu

Supaya maju kita kaum ibu

Sebab kita lihat kaum laki-laki

Sangat sungguh keras di hati

Menuntut ilmu berhati-hati

Sesudah dapat baru berhenti

Sebelum dapat mundur tak suka

Tuntutlah ia sehabis tenaga

Jangan lekas berputus asa

Sebab ilmu itu pangkal bahagia

Ilmu itu sangat berharga

Mahal dari emas suasa

Ataupun dari intan mutiara

Pengetahuan itu lebih berguna

Kalau ilmu ada di dada

Serta manis tutur bahasa

Murah dapat perak tembaga

Didapat dengan jalan mulia

Knowledge is an eternal treasure

Certainly not to left behind

Though on the land or in the ship

It might become a hold

Because the mothers nowadays

Rarely seek knowledges

Until lack of knowledges

Take the mirror accross the land

But, if we persistanly learn

All knowledges can be pursued

So we might become teacher

If we have been already smart

If we have been already skillful

All intentions are easy to reach

To be able to climb as squirrel

Even the smell is good like lotus flower

So that is why, $\mathrm{O}$ my friends

One by one, let us

Immediately seek knowleges

In order to be onward, we are the mothers

Because we see the men

Persistent indeed in the heart

Seeking knowledges carefully

After reaching then stopping

Before giving up

Seek it persistently

Do not be hopeless

Because the knowledge is the mother of happiness

The knowledge is so valuable

More than suasa gold

Or from dioamond and pearl

Knowledge is more useful 
If knowledge is in the chest

In a noble way

Also good in words

Easy to get silver and copper

More specifically, poem of Adjakan (Doenia Istri) shows an effort to encourage women who have become a mother, to realize that her position as a mother with a lot of social attribution, still need knowledge. The status of "mother" is not a sign of cessation of opportunities for women to study.

Alteration of phase that experienced by women, starting from unmarried until to be a wife and then a mother is an important part of women's lives. So, the restless that be an indicators of the emergence of an invitation for women to not stop studying as expressed in the poem, in my opinion, can be traced in two phases of life entered by women. First, when a woman get married. Alteration in the status of women in judicially and customary are legalized, directly changing the order of the previous women themselves. Beauvoir (2003: 230) states that in marriage, women indeed get some wealth given to her in this world; legitimate guarantees protecting her from adverse actions of men. Nevertheless, women become slaves of men. When married, women acting as the head of economy, women bear the name of her husband; believe on the religion that believed by her husband, joined her husband's class, her husband's environment; she fused in her husband's family, and becomes a part of her husband. Thus, she has absolutely delinked her past and join the world of her husband; she gave her husband herself, her virginity, and her strong loyalty. She lost the legal rights that owned by unmarried women.

Second, when women become mothers. When became a mother, according to Beauvoir (2003) woman act in the position of her own mother. Thus, women have to deal with the household affairs, children and husband purposes, as well as other matters related to the maintenance of the house. Women do not have another job besides maintaining and providing herself for her family life, pure without variation; without changes, she continued her descent, assured that the rhythm of the days gone by being the same, also the sustainability of her household, included checking whether the door was locked.

The routine, in the 18th century criticized by liberal feminists in Europe because it is considered to have reduced the chances of women to obtain education. One of them was Mary Wollstonecraft that demanding people to give education to women, as well as to men because all men are entitled to an equal chance to develop reasoning and moral capacity (via Wiyatmi Tong, 2013). The idea was submitted by Wollstonecraft as discussed by Arivia (2013) because of concern to see majority of women in Europe who are married should stay at home and not productive. Most of them are middle-class women who are married with employers or professionals already established. She offers to the women in that time to realize that the power of mind and body are the most important things, not be a slave to her husband and children.

The problem of educational inequality that has been around of women later developed into a larger public issues. Every feminist movement has a different analysis of these issues. Within the framework of radical feminism, for example, Arivia (2006: 413) considers that "Injustice for women in education is caused by patriarchal system that prevailing in the local community." This situation is that trigger the boundaries of space between men and women based on gender notch. As disclosed by Ann Forman in Arivia's analysis (2003) that at last men become very existence in the social, business, industry world, and also in the family, while for women, her place often in the home.

Furthermore, the poem of Adjakan also presents issues of education which relates to properties of women. This relationship is formed by massive metaphor, that is by presupposing and likening that knowledge is a treasure. Based on this thought, so the further assumption is that knowledge can become the source of pearl and gold as women properties. If the women have knowledge and be good in words, they own silver and copper in a noble way. The thoughts point out that women orientation in the era could not be separated from issue of wealth.

Different from issue that Tjoemboean revealed, the issue of wealth in poem of Adjakan is more potentially concerning to social and economic issues that happened to middle and lower class women. In the middle political, social, and economic situations in 1930s in Indonesia, the encouragement to take education on women, in my opinion, had relationship with issue of women traffic that happened in the era. Wieringa (1999) revealed this situation through interview conducted with a woman activist who was also a teacher at Taman Siswa and a member of Isteri Sedar. In the interview, the woman activist said that women traffic was manifested by various ways. For example, the big bosses who were giving money to their parents and particular family, especially to the poor farmer family that had maidens then married them. If they have gotten ten maidens, they took them to Jakarta or Singapore. The maidens were sale right there. This problem also became the crucial issue that was 
discussed in The 2nd Congress of United Indonesian Women Organization (Persatuan Perkumpulan Istri Indonesia) in Surakarta. PPII is an organization that covered about fifty organizations of women in some regions of Indonesia.

In the situation, women became commodities that were sale. Especially women of the middle and lower class. Their bodies were exchanged with gold or other goods for the sake of family needs. Therefore, the stated issues in the poems, particularly about education which oriented to obtain properties, become highly correlated. Because, the properties become an important need for women so that they will be safe from things that endanger their selves.

The poem of Adjakan attempts to ensure women that knowledge can be a shield of women selves. It is reinforced by other evidences in verse "Knowledge is an eternal treasure/Certainly not to left behind / Though on the land or in the ship / It might become a hold". Sign of background scene, "land" and "ship" in the verse has similarity as Wieringa's finding about the journey of women that became the victim of women traffic when dispatched to Singapore. "Land" can be interpreted as a house or family that becomes women place to live. Then, "ship" is a part of journey that women have to pass when dispatched to Singapore through the sea. In the interview with the woman activist that Wieringa met, she stated that in 1935, Isteri Sedar organization did rescue the maidens from the ship.

On the second and the third problems, knowledge and education are associated with women desires to improve the quality of their selves. This is revealed in the verse "But, if we persistanly learn/All knowledges can be pursued / So we might become teacher/ If we have been already smart", and "If we have been already skillful/ All intentions are easy to reach/ To be able to climb as squirrel/Even the smell is good like lotus flower". In the verse, there is a women desire to be a teacher. If it is contextualized to women education growth in Northern Sumatera, in an interview with Ichwan Azhari, a historian in Northern Sumatera, in 1930s a number of school in Northern Sumatera were growing enough. It can be seen from the establishment of women's missionary school in Toba, all-girls school in the Sultanate Langkat, Muhammadiyah schools, and Taman Siswa.

In two important phases of women's lives, that is, when unmarried and married, women stay put in norms, customs and stereotypes construction that tend to be rigid so that gripped herself. Women are more difficult to recognize and actualize herself. Poem of Adjakan (Doenia Istri) expressly and critically responded to these conditions. In addition with doing repeated invitation for women to keep studying, this poem shows paradoxical facts about possessions that many hailed by women. In the lines, "The knowledge is so valuable / More than suasa gold / Or from dioamond and pearl / Knowledge is more useful", the poem offers a counterpoint thought to the mothers, that jewelry and wealth is not the most important things. That view at once strengthen provocation so as to the mothers do not arbitrarily stop studying.

\section{Conclusion}

Poem of Tjoemboean published by Perempoean Bergerak (1919) newpapers, and poem of Adjakan (Doenia Istri) published by Bintang Karo (1931) newpapers, are important poems to discuss with some reasons. First, the poems become a critical articulation instrument of women on issues pertaining to her life. Second, the poems show women movement issue against gender subordination that implemented through a suit demanding equality in obtaining education. Manifestations of critical ideas to the progress of women in poems of Tjoemboean and Adjakan (Doenia Istri) became one of the proofs that the bodied and gendered awareness have translated into political actions and social movements. In the midst of polarization and inter-ideology tension in Indonesian literature, once again, these poems show that a work of fiction, the poem, had involvement in the women's movement, especially women in Northern Sumatera.

\section{Acknowledgment}

The author would like to acknowledge and express gratitude to the Indonesia Endowment Fund for Education (LPDP), Aquarini Priyatna and Teddi Muhtadin for their support of Sartika Sari's research.

\section{References}

[1] Arivia, Gadis. Filsafat Berpersfektif Feminis. Jakarta: Yayasan Jurnal Perempuan (YJP). 2003.

[2] Arivia, Gadis. Feminisme: Sebuah Kata Hari. Jakarta: Kompas Media Nusantara. 2006. 
Beauvoir, Simone de. Second Sex: Kehidupan Perempuan. Translated by Toni B. Febriantono dan Nuraini Juliastuti. Jakarta: Pustaka Promothea. 2003.

[3] Gamble, Sarah. Pengantar Memahami Feminisme dan Postfeminisme. 2010.Yogyakarta: Jalasutra

[4] Hanani, Silfia. (December, 2011). Rohana Kudus dan Pendidikan Perempuan. portalgaruda.org.

[5] Mcdonald, Lisa. Feminisme dan Sosialisme. Australia: Resistance Book. 2001.

[6] Millet, Kate. Sexual Politics. New York: Garden City, Doubleday. 1970.

[7] Rosidi, Ajip. Ikhtisar Sejarah Sastra Indonesia. Bandung: Dunia Pustaka Jaya. 2013.

[8] Samboedja, Asep. Kronik Sejarah Sastra Indonesia (1908-2008). Bandung: Ultimus. 2011.

[9] Samry, Wannofri. Suara Perempuan Sumatera: Pers Perempuan Di Sumatera Utara pada Zaman Kolonial 1919-1942. Jurnal Analisis Sejarah, Volume 4, No. 2, 2014 @ Labor Sejarah, Universitas Andalas.

[11] Sumardjo, Jakob. (July, 1981). Rumah yang Damai: Wanita dalam Sastra Indonesia. Prisma.

[12] Wieringa. Saskia Eleonora. Penghancuran Gerakan Perempuan di Indonesia. Translated by Hersri Setiawan. Jakarta: Garba Budaya. 1999.

[13] Wiyatmi. Menjadi Perempuan Terdidik: Novel Indonesia, dan Feminisme. Yogyakarta: UNY Press. 2013.

\section{Bahan Bacaan:}

Perempoean Bergerak, Edisi 16 Juli 1919

Bintang Karo, Edisi Maret 1931 